For Debate...

\title{
Importance of occult haematuria found at screening
}

\author{
CAROLYN D RITCHIE, ELIZABETH A BEVAN, ST JOHN COLLIER
}

\begin{abstract}
A retrospective study of the results of dipstick testing and microscopical examination of urine from 10050 men undergoing health screening showed a prevalence of occult haematuria of $2 \cdot 5 \%$. Those patients with occult haematuria who were resident in the United Kingdom and registered with a general practitioner were identified and a questionnaire sent to their general practitioners asking what further investigations had been performed. The response rate was $92 \%$ (152/165 inquiries). Fifty nine general practitioners $(39 \%)$ had not instigated any investigations. Among the 76 patients who underwent some further investigations abnormalities were found in $21(28 \%)$; and among those fully investigated by examination of midstream urine, intravenous urography, and cystoscopy abnormalities were found in $12(50 \%)$. These included bladder neoplasms (two; one in a patient aged 37), epithelial dysplasia (one), staghorn calculi (one), and chronic reflux nephropathy (one).

It is proposed that occult haematuria should be fully investigated regardless of the age of the patient.
\end{abstract}

\section{Introduction}

The importance of occult haematuria as an early sign of urinary tract disease is well known by urologists, yet it is often inadequately investigated or is accepted as a benign condition. ' In younger patients haematuria most often results from urinary tract infections or disorders such as renal calculi, glomerulonephritis, or IgA nephropathy. ${ }^{23}$ Athletic haematuria is a transient phenomenon that occurs after prolonged, vigorous exercise and is unlikely to be persistent. ${ }^{+}$In patients over 40 , however, a major urinary tract lesion will be found in about $20 \%$ of those with confirmed microscopical haematuria, and in at least $10 \%$ the lesion will be malignant. ${ }^{15}$ Even when no disorder is diagnosed some patients will develop an important lesion within the next few years. ${ }^{5}$

Cancers of the urinary tract are fairly common, accounting for more than $15 \%$ of all registrations of cancer among British men. ${ }^{6}$ Furthermore, the severity of haematuria is not related to the severity of the urological lesion. ${ }^{5}$ As a carcinoma found as a result of investigating microscopical haematuria may be at an early, treatable stage it is important that haematuria detected during routine screening should be thoroughly investigated. ${ }^{2}$

The development of dipstick testing has simplified the detection of occult haematuria. ${ }^{7}$ The Labstix test detects haemoglobin

BUPA Medical Research, London WC1X 8DU

CAROLYN D RITCHIE, PHD, head of research

ELIZABETH A BEVAN, BSC, senior research assistant

University of Cambridge Clinical School, Department of Surgery, Addenbrooke's Hospital, Cambridge

ST JOHN COLLIER, FRCS, research fellow

Correspondence and requests for reprints to: Dr Ritchie. (product information chart, Ames Division, Miles Laboratories Ltd, Stoke Poges, Slough); thus haemolysis will not affect the results and failure to find red cells by microscopical examination does not rule out the presence of blood in the urine when the dipstick gives a positive result. Nevertheless, false positive results to the dipstick test do occur. ${ }^{8}$

Health screening is performed on 45000 people a year at the BUPA Medical Centre. Testing for the presence of occult haematuria using dipsticks (Labstix) is an integral part of the screening. Results are reported to the general practitioners of those undergoing screening, who undertake any further investigation thought to be appropriate.

We performed a retrospective study of the results of dipstick examination of the urine in 10050 men to assess the prevalence of occult haematuria. A follow up questionnaire was sent to the general practitioners of men found to have occult haematuria to determine the extent and outcome of subsequent investigations.

\section{Subjects and methods}

The subjects were men who attended the London screening centre for the first time between 28 February 1983 and 16 January 1984 in whom dipstick testing for blood in the urine gave a positive result.

Urine testing was performed on a midstream sample using dipsticks (Labstix). When a positive result for blood was obtained the sample was sent to the laboratory, where it was retested by dipstick and examined microscopically within four hours. The results of all three tests were reported to the general practitioner.

A questionnaire was sent to the general practitioners of patients with confirmed occult haematuria (that is, patients for whom both dipstick tests were positive) requesting details of further investigations carried out as a result of the screening findings. If no reply was received a second letter was sent.

\section{Results}

The figure shows a flow chart of the follow up procedure. Out of 10050 men who were screened for the first time, $303 \mathrm{had}$ a positive result on dipstick testing at screening; 255 of these results were confirmed at the laboratory by microscopy or dipstick testing, or both. Thus the prevalence of occult haematuria was $2.5 \%$ $(255 / 10050)$

Follow up was not attempted for 90 patients, most of whom were not resident in Great Britain or not registered with a general practitioner. The response rate to the follow up questionnaire was $92 \%(152 / 165$ inquiries; table I). Of 70 patients who were not investigated after screening, eight were no longer registered in the practice, two defaulted, and one had died. Six patients were already under investigation and were not considered further as their haematuria had not been first detected at screening.

Table II shows the investigations that were carried out on the remaining 76 patients classified according to the patients' ultimate 
investigation. Abnormalities were found in $21(28 \%)$ of the group as a whole but in $12(50 \%)$ of those undergoing full investigation - that is, examination of midstream urine, intravenous urography, and cystoscopy.

Table III shows the abnormalities that were detected in patients whose investigations included intravenous urography with or without cystoscopy, and their original screening results. Microscopy at screening yielded negative results in four of the patients, and both bladder tumours were found in patients with only a + dipstick result.
Possible reasons for not investigating haematuria include the age of the patient, the view that trace amounts of blood are not important, and the view that negative results on microscopy imply a false positive dipstick result. Age does not appear to have been an important factor in our subjects, as the average age of those who were investigated was similar to the age of those who were not (49 and 46 years respectively). Likewise, the degree of positivity of the dipstick result was similar in the two groups. Interestingly, the patients subsequently found to have bladder tumours or epithelial dysplasia had + haematuria at screening.

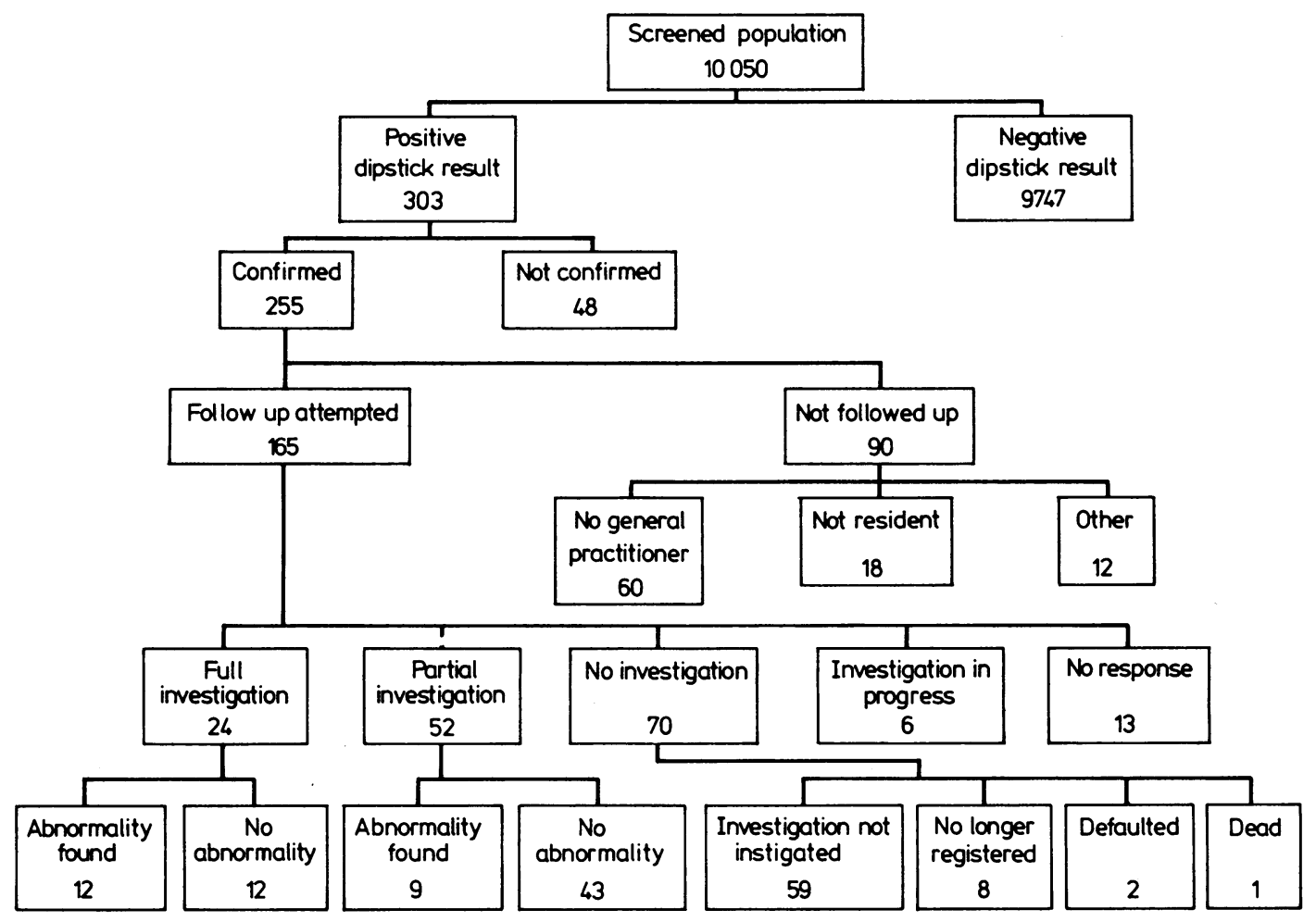

Flow chart of follow up procedure.

\section{Discussion}

Little is known of the prevalence of asymptomatic microhaematuria. Larcom and Carter showed that $1 \cdot 2 \%$ of young men had more than two red blood cells/high power field, ${ }^{9}$ whereas Froom et al in annual examinations of young men found a point prevalence of $5 \cdot 2 \%$ for two or more erythrocytes/high power field. ${ }^{10}$ When dipsticks have been used to detect haematuria positive findings have been reported in $1.9 \%$ of hospital outpatients, ${ }^{11} 3.5 \%$ of middle aged working men, ${ }^{12}$ and over $16 \%$ of adults undergoing multiphasic screening. ${ }^{13}$ It is not possible to know how much of these differences reflects variations in the sensitivity of the methods and how much is due to true differences in prevalence; nevertheless, our finding of occult haematuria in $2.5 \%$ of men attending a screening centre is in general agreement with most published reports.

The high response rate $(92 \%)$ to the follow up questionnaire allows us to be confident about the extent of investigation instigated by the general practitioners. Thus we were interested to find that $39 \%$ of general practitioners took no further action. In those patients who were fully investigated by testing of midstream urine, intravenous urography, and cystoscopy, however, abnormalities were found in half. These included serious disease: bladder tumours, epithelial dysplasia, staghorn calculi, and chronic reflux nephropathy. It is open to speculation what would have been found if all patients had been fully investigated. Fraser $e t$ al obtained similar results in hospital outpatients ${ }^{11}: 59 \%$ of patients with occult haematuria detected by routine screening were not referred for further laboratory tests or investigations.
TABLE I-Outcome of follow up of men with haematuria detected by screening

\begin{tabular}{|c|c|c|c|c|c|c|}
\hline & \multirow[b]{2}{*}{ No } & \multirow{2}{*}{$\begin{array}{c}\text { Age range } \\
\text { (mean) } \\
\text { (years) }\end{array}$} & \multicolumn{3}{|c|}{$\begin{array}{c}\text { Dipstick } \\
\text { result }\end{array}$} & \multirow{2}{*}{$\begin{array}{c}\text { No (\%) } \\
\text { positive on } \\
\text { microscopy }\end{array}$} \\
\hline & & & + & ++ & +++ & \\
\hline \multirow{4}{*}{$\begin{array}{l}\text { No reply to inquiry } \\
\text { Not investigated } \\
\text { Investigation for haematuria in } \\
\text { progress before screening } \\
\text { Further investigation after } \\
\text { screening }\end{array}$} & 13 & $23-63(46)$ & 8 & 2 & 3 & $6(46)$ \\
\hline & 70 & $26-72(46)$ & 51 & 13 & 6 & \\
\hline & 6 & $28-57(43)$ & 1 & 2 & 3 & $4(67)$ \\
\hline & 76 & $21-72(49)$ & 48 & 16 & 12 & $52(68)$ \\
\hline Total & 165 & & 108 & 33 & 24 & $82(50)$ \\
\hline
\end{tabular}

TABLE II-Extent of investigation of patients followed up by their general practitioners

\begin{tabular}{|c|c|c|}
\hline & Total No & $\begin{array}{c}\text { No (\%) with } \\
\text { abnormality found }\end{array}$ \\
\hline Repeat dipstick testing & 8 & 0 \\
\hline Examination of midstream urine & 30 & $4 \star(13)$ \\
\hline $\begin{array}{l}\text { Examination of midstream urine and } \\
\text { intravenous urography }\end{array}$ & 14 & $5+(36)$ \\
\hline Examination of midstream urine, & & \\
\hline intravenous urography, and cystoscopy & 24 & $12 \dagger(50)$ \\
\hline Total & 76 & $21(28)$ \\
\hline
\end{tabular}

$\star$ Few red cells or haemoglobin.

† See table III. 
TABLE III-Abnormalities detected in 17 patients according to extent of investigation

\begin{tabular}{lcccc} 
Lesion & $\begin{array}{c}\text { No of } \\
\text { patients }\end{array}$ & $\begin{array}{c}\text { Patients' } \\
\text { ages } \\
\text { (years) }\end{array}$ & $\begin{array}{c}\text { Screening } \\
\text { dipstick } \\
\text { result }\end{array}$ & $\begin{array}{c}\text { Screening } \\
\text { microscopy } \\
\text { result }\end{array}$ \\
\hline
\end{tabular}

Investigated by examination of midstream urine and intravenous urography

\begin{tabular}{|c|c|c|c|c|}
\hline Renal calculi & 4 & $\left\{\begin{array}{l}35 \\
44 \\
49 \\
56\end{array}\right.$ & $\begin{array}{r}+ \\
+++ \\
++ \\
+++\end{array}$ & $\begin{array}{l}\text { Negative } \\
\text { Positive } \\
\text { Positive } \\
\text { Positive }\end{array}$ \\
\hline Smooth dilatation in major calix & 1 & 47 & + & Positive \\
\hline
\end{tabular}

Investigated by examination of midstream urine, intravenous urography, and cystoscopy

\begin{tabular}{|c|c|c|c|c|}
\hline Epithelial dysplasia & 1 & 44 & + & Positive \\
\hline Papillary tumour of bladder & 2 & $\left\{\begin{array}{l}37 \\
60\end{array}\right.$ & $\begin{array}{l}+ \\
+\end{array}$ & $\begin{array}{l}\text { Positive } \\
\text { Positive }\end{array}$ \\
\hline $\begin{array}{l}\text { Staghorn calculus } \\
\text { Chronic reflux nephropathy } \\
\text { Postmeatal stricture }\end{array}$ & $\begin{array}{l}1 \\
1 \\
1\end{array}$ & $\begin{array}{l}52 \\
35 \\
42\end{array}$ & $\begin{array}{r}++ \\
+ \\
++\end{array}$ & $\begin{array}{l}\text { Positive } \\
\text { Negative } \\
\text { Positive }\end{array}$ \\
\hline $\begin{array}{l}\text { Prostatic urethritis with contact } \\
\text { bleeding }\end{array}$ & 1 & 51 & + & Positive \\
\hline Bladder outflow obstruction & 2 & $\left\{\begin{array}{l}59 \\
55\end{array}\right.$ & $\begin{array}{l}+ \\
+\end{array}$ & $\begin{array}{l}\text { Positive } \\
\text { Positive }\end{array}$ \\
\hline Prominent vessels at bladder neck & 3 & $\left\{\begin{array}{l}61 \\
60 \\
52\end{array}\right.$ & $\begin{array}{r}+++ \\
++ \\
+\end{array}$ & $\begin{array}{l}\text { Positive } \\
\text { Negative } \\
\text { Negative }\end{array}$ \\
\hline
\end{tabular}

One difference that emerged was in the results of microscopy, which were positive in $68 \%$ of the investigated group compared with $29 \%$ of the group not investigated. Although most of the serious abnormalities were found in patients with positive results on microscopy, this may not always be the case, and the importance of negative results on microscopy in our patients cannot be determined without knowing what abnormalities exist in the group who were not investigated.

We consider that our results support the view that all confirmed cases of occult haematuria should be fully investigated. ${ }^{1514}$ The recommendation that such investigation should be confined to patients aged over 40 years is debatable, ${ }^{10}$ as one of the two bladder tumours found in this study was in a patient of 37 .

\section{References}

1 Golin AL, Howard RS. Asymptomatic microscopic hematuria. F Urol 1980;124:389-91

2 Woodhouse CRJ. Symptomless abnormalities: microscopic haematuria. $\mathrm{Br} \mathcal{J}$ Hosp Med 1982;27:163-8.

3 Batlle DC. IgA glomerulonephritis, asymptomatic hematuria, and systemic disease. Arch Intern Med 1981;141:1264-5.

4 Anonymous. The haematuria of the long distance runner. Br Med $\mathcal{J} 1979 ;$;i: 159.

5 Carson CC III, Segura JW, Greene LF. Clinical importance of microhematuria. IAMA 1979.241:149-50.

6 Office of Population Censuses and Surveys. Estimates of cancer registrations 1976. OPCS Monitor MB1 80/1.

7 Leonards JR. Simple test for hematuria compared with established tests. FAMA 1962;179:807-8. 8 Weaver MR, Gibb 1. Urinalysis for blood: questionable interpretation of reagent strip results. Clin Chem 1983;29:401-2.

9 Larcom RC Jr, Carter GH. Erythrocytes in urinary sediment: identification and normal limits with a note on the nature of granular casts. F Lab Clin Med 1948;33:875-80.

10 Froom P, Ribak J, Benbassat J. Significance of microhaematuria in young adults. Br Med $\mathcal{J}$ 1984;288:20-2.

11 Fraser CG, Smith BC, Peake MJ. Effectiveness of an outpatient urine screening program. Clin Chem 1977;23:2216-8.

12 Vallancien G, Cadranel J, Jardin A. What should be done in the presence of isolated microscopic hematuria in the work environment? Presse Médicale 1985;14:1279-81

13 Mariani AJ, Luangphinith S, Loo S, Scottolini A, Hodges CV. Dipstick chemical urinalysis: an accurate cost-effective screening test. I Urol 1984;132:64-6.

14 Benson GS, Brewer ED. Hematuria: algorithms for diagnosis. FAMA 1981;246:993-5.

(Accepted 4 December 1985)

\section{A new antivivisectionist libellous statue at Battersea}

The Greater London Council provided a site in Battersea Park for the unveiling on 12 December 1985 of Nicola Hicks's bronze sculpture "The Brown Dog," funded by the British Union for the Abolition of Vivisection and the National Anti-Vivisection Society. The inscription on the statue reads:

In memory of the Brown Terrier Dog Done to Death in the Laboratories of University College in February 1903 after having endured Vivisections extending over more than two months and having been handed over from one Vivisector to another till death came to his Release. Also in Memory of the 232 dogs vivisected in the same place during the years 1902-3.

$$
\begin{aligned}
& \text { Men and Women of England } \\
& \text { How long shall these things be? }
\end{aligned}
$$

This monument replaces the original memorial of the Brown Dog erected by public subscriptions in Latchmere Recreation Ground, Battersea in 1906. The sufferings of the Brown Dog at the hands of vivisectors generated much protest and mass demonstrations. It represented the revulsion of the people of London to vivisection and animal experimentation. This new monument is dedicated to the continuing struggle to end these practices. After much controversy the former monument was removed in the early hours of $10 \mathrm{March} 1910$. This was the result of a decision taken by the then Battersea Metropolitan Borough Council, the previous Council having supported the erection of the memorial.

Animal experimentation is one of the greatest moral issues of our time and should have no place in a civilised society. In 190319084 animals suffered and died in British Laboratories. During 19843497335 experiments were performed on live animals in Great Britain. Today, animals are burned, blinded, irradiated, poisoned and subjected to countless other horrifying cruel experiments in Great Britain.

There can be few doctors still alive who participated in the struggle against the first "brown dog," and the truth bears repetition. In December 1902 a dog was fully anaesthetised for Professor Starling to tie a pancreatic duct. The dog recovered fully and was anaesthetised again on 2 February 1903, when its abdomen was opened, the pancreas inspected, and the incision then closed. The dog, still under anaesthesia, was transferred to a lecture theatre, where $\mathrm{Dr}$ W M Bayliss stimulated the nerve to the salivary glands, after which, still anaesthetised, the dog was killed by Dr Henry Dale, who took the pancreas for section. The antivivisectionist council alleged painful experiments without anaesthesia, whereupon Dr Bayliss sued the honorary secretary of the Antivivisection Council for libel and was awarded $£ 2000$ in damages and costs.

The International Antivivisectionist Council erected the first brown dog memorial in 1906, prompting years of protests, marches, and demonstrations, especially by medical students, against whom the statue was protected by a 24 hour police guard. The inscription was regarded by doctors at the time as "a disgraceful insult to a great teaching body and the whole profession" (Osler), "not much better than an indecent exhibition, obscene picture, or blasphemous oratory" (Stephen Paget), "a gross, deliberate, carefully thought out lie, one of the most brutal and impudent lies that has ever been invented, even by an anti-vivisection society," "a lie which received condign punishment from a British Jury" (Lancet), while the British Medical fournal quoted Pope on another monument:

"Where London's column pointing at the skies, Like a tall bully, lifts the head, and lies."

By English law anyone can libel the dead even by repeating words that have been declared libellous by a court during the lifetime of the libelled. Nothing can legally stop the antivivisectionists from reprinting their lies of the early 1900s. It is amazing, however, that 74 years after the first brown dog memorial was removed and destroyed by Battersea Borough Council and the inscription excised from the base of the fountain, a public authority, the Greater London Council, should allow the libel to be reincarnated in public park as one of its last actions before its extinction in a few months.

The next authority responsible for Battersea Park should remove this degrading, libellous, and offensive memorial.

\section{Do nylon support stockings cause loss of hair on the legs?}

No. The questioner is probably trying to explain the curious area of baldness regularly apparent on the lower and outer third of all men's legs. There is no known satisfactory explanation for the paucity of terminal hair on this part of the integument. It is not related to arterial insufficiency, well known to be responsible for hair loss on the dorsal surface of the feet and toes in men. Nor is it related to friction of socks or trousers or nylon support hose since it is seen in those who wear shorts; it does not affect the medial side of the lower leg, where the friction should be the same; and it is seen in men who do not wear nylon support hose. The reason for this leg baldness is as obscure as the reason for the male distribution of sexual hair. Perhaps it is the same reason.-ALAN B SHRANK, consultant dermatologist, Shrewsbury. 